\title{
Drivers of Human Resource Development Climate: OCTAPAC Culture- A Study on Selected Aviation Companies, Bangalore, India
}

\author{
Archana Sitamma Reddy* Navneel Prasad \\ Department of Management, University of Fiji, Private Mail Bag, Lautoka, Fiji Islands
}

\begin{abstract}
The subject will rotate around the drivers of the Human Resource Development atmosphere through OCTAPAC culture meaning Openness, Confrontation, Trustiness, Autonomy, Proactivity, Authenticity, and Collaboration. It will center on the OCTAPAC culture within the governing body and how it prompts the development of the human asset and additionally prompt proficiency and efficiency in Aviation organizations in Bangalore. Moreover, a strong atmosphere generally is essential for human asset developing to be adequately actualized. Such steady atmospheres comprise not just direction and logical argument management's commitment but also great workforce approaches and positive posture towards advancement which is achievable by having an OCTAPAC culture. A good HRD mechanism such as rewards, career planning, acknowledgment and so forth are factors that bring about a positive working environment and culture in an organization and which also promotes effective communication and teamwork.
\end{abstract}

Keywords: OCTAPAC culture, Human Resource Development mechanism, Aviation

DOI: $10.7176 / \mathrm{EJBM} / 11-32-04$

Publication date: November $30^{\text {th }} 2019$

\section{Introduction}

Aviation in India is comprehensively divided into military and civil aviation which is the fastest developing market around the globe. The civil aviation industry in India has risen as one of the quickest developing ventures in the nation during the last three years. India is at present considered the third biggest domestic civil aviation market in the globe (India Brand Equity Foundation. 2018).

The airlines in India connect more than 80 urban areas crosswise over India and furthermore work abroad courses after the liberation of Indian aviation. Nonetheless, an extensive area of the nation's air transport potential stays undiscovered, even though the Mumbai-Delhi air passageway was positioned tenth by Amadeus in 2012 among the world's busiest routes. As indicated by International Air Transport Association IATA, India will uproot the UK for third place in 2025. The Aviation industry has introduced another time of extension, driven by elements, for example, low-cost carriers, current airplane terminals, Foreign Direct Investment in domestic carriers, information technology interventions and developing an emphasis on the local networks (World Blaze. 2018).

Furthermore, just like any other companies' aviation companies also have to closely monitor its human resource development plans and organizational cultures for productivity which the study will try to find as in the HRD climate in aviation companies. Human Resource Development (HRD) is the system for helping workers build up their own and hierarchical aptitudes, learning, and capacities. Human resource development in companies opens doors that representatives look for when they think about career growth and development. The capacity and support which help employees in developing their aptitudes help to inspire representatives (Kalburgi, M Srinivas. 1984).

Human Resource Development includes opportunities such as; Employee training which could be either on the job training such as job rotation or mentoring or of the job training through conferences and workshops and Employee career development through proper guidance to build competencies and for encouragement purpose and so forth (K. Aswathappa, 2010).

The importance of studying HRD Climate in any organization or the aviation sector gives a clearer picture of the various components such as the general atmosphere, OCTAPAC (Openness Confrontation, Trustiness, Autonomy, Proactivity, Authenticity, Collaboration) and the HRD mechanism. The organizational culture is the key to achieve organizational excellence and the function of HR and other departments is responsible for the creation and management of culture in an organization. Escalating the importance of culture is also partly a result of the increasing turbulence, Complexity, and unpredictability faced by organizations in their internal and external environments. Culture also fosters adaptability by providing a clear set of principles to follow when designing strategies to cope with new circumstances, therefore, the topic selected has importance as it will assist to;

(Srimannarayana, M., 2007) Firstly; to identify and measure the perceived organizational culture and its various dimensions which will give an idea as to how the executives and non-executives in the aviation 
companies perceive culture which will assist to identify the level of OCTAPAC culture (Openness Confrontation, Trustiness, Autonomy, Proactivity, Authenticity, Collaboration), within the aviation companies as well as other companies in competition and it will evaluate the effectiveness of OCTAPAC (Openness Confrontation, Trustiness, Autonomy, Proactivity, Authenticity, Collaboration), culture in the aviation sector.

Secondly, study the drivers of HRD (Human resource development), the climate in the aviation sector, one approach to achieve this is to direct a social appraisal or review of the association through worker studies, center gatherings or meetings. Furthermore, to identify the hierarchical structure used in aviation companies to empower change also, to find better approaches to achieve work errands. Utilize groups for one-time extends. Moreover, To analysis, if each gathering, each training program correspondence to individuals incorporates social informing and fortifies the qualities, mission, and conventions and finally, the topic is important for the study to see if everybody is included which is collaboration if not then suggest numerous approaches to get individuals included by cross-practical groups (Wani, T. A. 2013).

The need for this study is to see the degree of Openness, Confrontation, Trust, Autonomy, Proactivity, Authenticity, and Collaboration within the organization. Besides, as Human resource development (HRD) culture is fundamental for encouraging Human resource development climate therefore, the study will attempt to discover to what extent HRD culture deals with the Openness, Confrontation, Trustiness, Autonomy, Proactivity, Authenticity and Collaboration and promoted in the aviation sector (Tripathi, S. and Tripathi, N., 2002), Moreover, the study will administer the implementation of HRD mechanism such as training, performance appraisal, career planning, feedback, rewards, potential appraisal and employee's welfare which usually brings in a good working culture and in long run lead towards a friendly working environment as well as productivity and organizational excellence.

For organizational excellence, organizations need to retain their employees as they play a vital role. Companies need to find factors motivating employees with special reference to OCTAPAC culture and also focus on creating a climate whereby employees can work freely and feel appreciated by management as well as contribute towards the common goals of an organization. HRD mechanism plays an important role here as the various HRD mechanisms used such as training for employees, performance appraisals, rewards, and career planning can boost employee morale. Creating a good working environment where employees can communicate freely, high motivating factors and identifying the factors which create barriers in an organization are few of the main problems in any organizations, therefore, the study will aim to find OCTAPAC culture level in the aviation sector and the HRD mechanism used (Famina, A. 2009).

The scope of the study focuses on three aspects which lead to an advancement atmosphere in associations and efficiency. The three perspectives which are canvassed in the study are General atmosphere, OCTAPAC culture, and the HRD instrument/mechanism. Corporate culture is it resembles the central core of an organization. On the off chance that an organization doesn't put resources into building up a decent culture, at that point it's probably going to experience difficulty holding quality representatives for the whole deal, subsequently, the venture will accentuation on the organization atmosphere and culture and the component utilized as a part of the flight segment to make a decent workplace as well as hold great workers for general greatness of the organization.

The undertaking will likewise study in-depth on the ways the flight segment in Bangalore is creating an atmosphere for workers to find, create and utilize their full abilities for the association, the capacity of an association to pull in the hold and rouse capable representatives.

The main objectives of the study were to firstly, study the drivers of the human resource development climate in the aviation sector in Bangalore. Secondly, to evaluate the effectiveness of OCTAPAC (Openness Confrontation, Trustiness, Autonomy, Proactivity, Authenticity, Collaboration) culture in the aviation sector in Bangalore and finally, to study the implementation of HRD mechanism in the aviation sector for productivity and excellence in the organizations.

\section{Three components of HRD Atmosphere}

\subsection{General atmosphere}

The accompanying variables fill in as an empowering power to improve Human asset advancement atmosphere: Top management philosophy and style, a faith in the ability of individuals, a participating approach, transparency and receptivity to recommendations from subordinates is a portion of the measurements that add to the making of a positive HRD atmosphere (Famina, A. 2009).

Personnel policies, Personnel approaches that show high worry for representatives and underline value and objectivity in evaluations, strategies that stress adequate asset assignment for welfare and formative exercises, strategies that accentuate a communization state of mind and trust among the general population go far in making the HRD atmosphere.

Positive mentality/attitude towards improvement and development and an accommodating and strong state of mind concerning HRD and workforce individuals assume an exceptionally basic part in producing the HRD 
atmosphere. On the off chance that the individual conduct of these specialists isn't strong; the HRD atmosphere is probably going to be vitiated (Purang, P. 2006).

The commitment of line supervisors/managers, the dedication of line chiefs to the advancement of their subordinates is an essential determiner of HRD atmosphere and on the off chance that line chiefs will invest a piece of their energy for their subordinates, it is probably going to have a positive effect.

\subsection{HRD culture (OCTAPAC)}

HRD culture is fundamental for encouraging the HRD atmosphere. The HRD culture manages the degree to which OCTAPAC (Openness Confrontation, Trustiness, Autonomy, Proactivity, Authenticity, Collaboration) are esteemed and advanced in the association. HRD Climate is useful in the fulfillment of committed objectives of an individual, society, and association. It expands the capacities and productivity of an individual and is probably going to reflect itself over the long run in the prosperity of the individual and institution (Wani, T. A. 2013, Srimannarayana, M., 2007).

OCTAPAC Culture

\begin{tabular}{|c|l|}
\hline O-Openness & $\begin{array}{l}\text { It can be characterized as an unconstrained articulation of sentiments freely without much } \\
\text { hesitation and the sharing of these without retentiveness. Transparency is in headings, } \\
\text { getting and giving. Both these may identify with thoughts, input (counting feedback), and } \\
\text { sentiments. }\end{array}$ \\
\hline C-Confrontation & $\begin{array}{l}\text { Confrontation can be characterized as confronting instead of shying without end from } \\
\text { issues. It likewise infers further examination of relational issues. This includes taking up } \\
\text { challenges i.e. confronting an issue and working together with others to discover an answer } \\
\text { to the issue. } \\
\text { The result of the encounter will be better enhanced critical thinking, and readiness to } \\
\text { manage issues and with 'troublesome' workers. }\end{array}$ \\
\hline T- Trustiness & $\begin{array}{l}\text { Belief, dependency, and confidentiality of information. The employees trust each other and } \\
\text { can rely upon to do whatever they say they will. }\end{array}$ \\
\hline A-Autonomy & $\begin{array}{l}\text { It is the willingness to use power without fear and helping others to do the same. } \\
\text { Employees have some freedom to act independently within the boundary imposed by a job. }\end{array}$ \\
\hline P- Proactivity & $\begin{array}{l}\text { Employees are action-oriented, willing to take initiative for a change. } \\
\text { They anticipate issues and act or respond to the needs of the future able business, all such } \\
\text { things can also be used as the indicators of pro-action, including better capital management. }\end{array}$ \\
\hline A-Authenticity & $\begin{array}{l}\text { It is the value underlying the trust; It is the feelings of a person to acknowledge he/she has } \\
\text { and accept him/her as well as others who relate to him/her as persons. }\end{array}$ \\
\hline C-Collaboration & $\begin{array}{l}\text { It involves working together and using one another's strength for common use. } \\
\text { Individuals share their concerns with each other rather than solving it themselves and } \\
\text { prepare strategies, work out plans of action and implement them together. }\end{array}$ \\
\hline
\end{tabular}

\subsection{HRD Mechanism}

Every one of the structures, frameworks, and systems that a company employs enables its representatives to gain and reinforce their abilities are seen under HRD components. These components or frameworks or procedures can be utilized to encourage a great HRD atmosphere in the association all in all and administrative and no managerial specifically.

Human asset improvement is the way toward expanding human capabilities through learning, aptitudes, mentalities, and involvement in the association. This is the demonstration of making individuals working in the association as the association needs to achieve the activity. It is the estimation of hierarchical excellence (Purang, P. 2006)

Human asset improvement is a vital piece of human asset administration. Principle regions of human asset administration are training and development, profession, arranging and authoritative advancement. Human asset administration achieves authoritative proficiency and adequacy through the successful utilization of human asset advancement work.

Vital HRD components, which constitute the piece of the HRD atmosphere and considered for the present examination are performance appraisal, career planning, grievance mechanism, feedback and counseling, training and development, employee welfare for quality work-life, job rotation, rewards, recruitment, and selection (Saraswathi, S. 2010). 


\section{Methodology}

This present study has been finished by overseeing the Questionnaire created by Rao and Abraham (1986). The importance of the HRD atmosphere can be very much checked or seen from the measure of significance that is given to the development of OCTAPAC culture in the Organization. T. V. Rao presented the idea of OCTAPAC culture as a decent dynamic method for structure associations. Later, Udai Pareek and T.V. Rao spearheaded the idea of HR Culture and propounded the OCTAPAC Culture containing seven values to be specific, Openness, Confrontation, Trust, Autonomy, Pro-movement, Authenticity and Collaboration, and Eighth value being E for Empowerment and Experimentation was later included and it progressed toward becoming OCTAPACE which gives the performance of an organization in its 8 values but the present study focuses on OCTAPAC culture and not OCTAPACE as it tries to identify and study the level of Openness Confrontation, Trustiness, Autonomy, Proactivity, Authenticity, Collaboration in the top ten airlines in Bangalore which is required to further study the current environment of the organization and HRD mechanism which could be used to improve the learning and development. The study focuses on studying the culture which includes the beliefs, attitudes, norms, and ethics of its employees and behavioral attributes as to how they interact and ethos of individuals or groups than the experimental attributes which involve the incentives.

The sample determination was on the accompanying parameters such as the nature of the examination, the possibility of evaluating the information and the Respondent eagerness. The sampling technique used was Judgmental and ten aviation companies in Bangalore were considered for research purposes with a sample size of 50 respondents who were holding diverse positions in the air craft's organization.

The primary data was gathered from the respondents with the assistance of a structured questionnaire as per 38 item HRD climate questionnaires by Dr. Udai Pareek (Srimannarayana, M., 2009 pg 138-141) The 38 questionnaire on a scale of 5 point scale ranging from (strongly agree) to 1 (disagree) to measure the elements of HRD culture which is divided into three categories namely the general climate, the OCTAPAC culture and HRD Mechanism.

The secondary data, the optional information was gathered from journals, articles published by various authors on HRD mechanism and climate, reports, aviation company's websites, textbooks of HRD, and Information available on the internet was also referred and considered for the study. Furthermore, the data were analyzed using graphs (bar/pie charts/histograms, etc.), tables, excel for data sorting and analysis, and SPSS (Statistical Package for Social Science Windows).

\section{Findings}

From the data collected from the 50 respondents it could be inferred that $56 \%$ were male respondents from various airlines in Bangalore and $44 \%$ female respondents, majority of the respondents which is $38 \%$ of the respondents were between the age group of 20-25 in the airline's companies in Bangalore. Furthermore, 24\% of the respondents were between the age group 40-45, 8\% 35-40, 16\% 25-30 and 14\% 30-35, whereas, $0 \%$ of the respondents were between the age groups of 45-50.

Their designations are as follows; $9(18 \%)$ are customer service agent of the airlines followed by team leader $7(14 \%)$, reservation service agent $6(12 \%)$, data entry $6(12 \%), 5(10 \%)$ administrative assistant, $4(8 \%)$ head cashier, 4(8\%) finance executive, 4(8\%) assistant manager, 3(6\%) revenue analyst, and 2(4\%) executive. They have been working in the present company for some time majority of the respondents from the airlines were having 0-5 years of experience which is $66 \%, 24 \%$ of respondents have $05-10$ years experience and $10 \% 10-15$ years of experience and $0 \%$ have 10-15 years of work experience in current airlines.

Finally, the total number of work experience they had which included past and present experience was, it can be stated that larger number of respondents have a total of $0-5$ years which is $29(58 \%)$ respondents whereas, $13(26 \%)$ respondents have 5-10years of total experience overall and $5(10 \%) 15$ and above years of experience and 3(6\%) respondents have 10-15years of experience the manufacturing sector today, human capital is still essential for most factories to carry out a variety of manual operations, in spite of the rapid advancement of automation technology and robotics.

The futuristic vision of "unmanned manufacturing" (Deen 1993) is forbiddingly expensive because all its hardware components need to be computer-controlled to freely communicate with each other; and yet, most of the outcomes are not promising (Sun \& Venuvinod 2001). By and large, factories equipped with relatively simple machinery controls will require continuous attendance of human operators; for example, textile mills, leather products, and medical appliances. With limited capital investments in production equipment, the main budget of their fixed costs lies in the workforce size (Techawiboonwong et al. 2006).

Concerning cost-effectiveness, labor planning always opts for the minimum amount of workers needed to deal with the daily operations, as well as the probable rate of disturbance (Lim et al. 2008). The workforce disturbance is often ascribed to absenteeism and turnover, which may result in considerable loss of productivity for any labor-intensive division (Easton \& Goodale 2002).

Buffering with redundant skilled workers (Molleman \& Slomp 1999) or relief workers (Redding 2004) 
might be a direct solution to absenteeism; however, the rising labor cost must be justifiable because underutilization of labor during low demand seasons is considered a waste of resources. Absenteeism is the measure of unplanned absences from the workplace due to some reasons like a personal emergency, accident, illness, etc. Turnover occurs when an active worker resigns from the company of his own accord, thus leaving a vacant post until a replacement is found. If such disturbance has caused many tasks to become unattended and overdue, the company is then vulnerable to overtime cost, shrunk capacity and productivity, extra queuing time, lost business income, etc. To prevent these deteriorate effects, optimizing the number of workers can be helpful. As a fundamental branch of knowledge in manufacturing business, workforce management will never fall behind the times. Therefore, it is worth an attempt to incorporate a novel methodology, such as HMS, into the state of the art of workforce sizing.

Category- wise Analysis:

4.1 General HRD Culture - Mean \& Percent

\begin{tabular}{|c|c|c|}
\hline Item & Mean & $\begin{array}{l}\text { Per } \\
\text { cent }\end{array}$ \\
\hline $\begin{array}{l}\text { The top management of this organization goes out of its way to make sure that employees enjoy } \\
\text { their work }\end{array}$ & 1.65 & 33.00 \\
\hline $\begin{array}{l}\text { Believes that human resources are an extremely important resource and that they have to be } \\
\text { treated more humanly. }\end{array}$ & 1.71 & 34.17 \\
\hline $\begin{array}{l}\text { Development of the subordinates is seen as an important part of their job by the } \\
\text { managers/officers herein. }\end{array}$ & 1.63 & 32.50 \\
\hline The personnel policies in this organization facilitate employees' development. & 1.75 & 35.00 \\
\hline $\begin{array}{l}\text { The top management is willing to invest their time and energy including other organizational } \\
\text { resources to ensure employees' development. }\end{array}$ & 1.96 & 39.17 \\
\hline $\begin{array}{l}\text { Senior officers/executive in this organization takes active interest in their juniors and helps } \\
\text { them learn their job. }\end{array}$ & 1.58 & 31.67 \\
\hline $\begin{array}{l}\text { People lacking competence in doing their jobs are helped to acquire competence rather than } \\
\text { being left unattended. }\end{array}$ & 1.63 & 32.50 \\
\hline $\begin{array}{l}\text { Managers in this organization believe that employee behaviour can be changed and people can } \\
\text { be developed at any stage of their life. }\end{array}$ & 1.79 & 35.83 \\
\hline $\begin{array}{l}\text { The psychological climate in this organization is very conducive to any employee interested in } \\
\text { developing oneself by acquiring new knowledge and skills. }\end{array}$ & 1.79 & 35.83 \\
\hline The top management makes efforts to identify and utilize the potential of the employees. & 1.67 & 33.33 \\
\hline $\begin{array}{l}\text { The organizations future plans awareness to managerial staff to help them develop their juniors } \\
\text { and prepare them for future. }\end{array}$ & 1.96 & 39.17 \\
\hline OVERALL (General HRD Climate) & 1.74 & 34.74 \\
\hline
\end{tabular}

Analysis and Interpretation of the General Human Resource (HRD) Climate in the Aviation companies, Bangalore:

The above depicts General HRD climate mean and percent of the aviation companies in Bangalore. The highest mean is 1.96 (39.17 percent), which is favorable and enables managerial staff to be aware of the plans so that it can also help them to develop furthermore, the top management is willing to invest their time including other organizational resources for employee success and growth.

The lowest mean of the general HRD climate is 1.58 (31.67 percent), which is not favorable as employees feel that the organization doesn't take an active interest to help them learn. The top management going out of the way to make sure employees enjoy work is an important factor that has a mean of 1.65 (33.00per cent) which is an average. Managerial top-level should pay attention to such factors to motivate and make the employees work to achieve common goals for which they should enjoy what they do at work. Also, it could be inferred from the 
mean and percent that the aviation companies do consider the general HRD climate factors such as believing Human resource as an important resource and fair treatment as the respondents mostly either strongly agreed or agreed to the statement and which has a mean of 1.71 (34.17).

\subsection{OCTAPAC Culture-Mean \& Percent}

\begin{tabular}{|c|c|c|}
\hline Item & Mean & $\begin{array}{l}\text { Per } \\
\text { cent }\end{array}$ \\
\hline \multicolumn{3}{|l|}{ OPENESS } \\
\hline $\begin{array}{l}\text { Employees in this organization are very informal and do not hesitate to discuss their personal } \\
\text { problems with their supervisors. }\end{array}$ & 1.71 & 34.17 \\
\hline People in this organization do not have any fixed mental impressions about each other. & 1.71 & 34.17 \\
\hline Employees are not afraid to express or discuss their feelings with their superiors. & 2.04 & 40.83 \\
\hline Employees are not afraid to express or discuss their feelings with their subordinates. & 1.83 & 36.67 \\
\hline OVERALL & 1.82 & 36.46 \\
\hline \multicolumn{3}{|l|}{ CONFRONTATION } \\
\hline $\begin{array}{l}\text { Employees in this organization take pains to find out their strengths and weaknesses from } \\
\text { their supervising officers or colleagues. }\end{array}$ & 1.75 & 35.00 \\
\hline $\begin{array}{l}\text { Employees are not afraid to express or discuss their feelings with } \\
\text { Their superiors. }\end{array}$ & 2.04 & 40.83 \\
\hline Employees are not afraid to express or discuss their feelings with their subordinates. & 1.83 & 36.67 \\
\hline $\begin{array}{l}\text { When problems arise people discuss these problems openly and try to solve them rather than } \\
\text { keep accusing each other behind the back. }\end{array}$ & 1.92 & 38.33 \\
\hline OVERALL & 1.89 & 37.71 \\
\hline \multicolumn{3}{|l|}{ TRUST } \\
\hline $\begin{array}{l}\text { People lacking competence in doing their jobs are helped to acquire competence rather than } \\
\text { being left unattended. }\end{array}$ & 1.79 & 35.83 \\
\hline $\begin{array}{l}\text { When any employee makes a mistake his supervisors treat it with understanding and help him } \\
\text { to learn from such mistakes rather than punishing him or discouraging him. }\end{array}$ & 1.71 & 34.17 \\
\hline People trust each other in this organization. & 1.67 & 33.33 \\
\hline OVERALL & 1.72 & 34.44 \\
\hline \multicolumn{3}{|l|}{ AUTONOMY } \\
\hline Employees are encouraged to experiment with new methods and try out creative ideas & 1.67 & 33.33 \\
\hline $\begin{array}{l}\text { Employees returning from training programmes are given opportunities to try out what they } \\
\text { have learnt. }\end{array}$ & 1.83 & 36.67 \\
\hline $\begin{array}{l}\text { Employees are encouraged to take initiative and do things on their own without having to } \\
\text { wait for instructions }\end{array}$ & 2.08 & 41.67 \\
\hline
\end{tabular}




\begin{tabular}{|c|c|c|}
\hline $\begin{array}{l}\text { Delegation of authority to encourage juniors to develop handling higher responsibilities is } \\
\text { quite common in this organization. }\end{array}$ & 2.00 & 40.00 \\
\hline $\begin{array}{l}\text { When seniors delegate authority to juniors, the juniors use it as an opportunity for } \\
\text { development. }\end{array}$ & 1.92 & 38.33 \\
\hline OVERALL & 1.96 & 39.17 \\
\hline \multicolumn{3}{|l|}{ PROACTIVITY } \\
\hline The top management makes efforts to identify and utilize the potential of the employees. & 1.79 & 35.83 \\
\hline Employees are encouraged to experiment with new methods and try out creative ideas & 1.67 & 33.33 \\
\hline $\begin{array}{l}\text { Employees are encouraged to take initiative and do things on their own without having to } \\
\text { wait for instructions }\end{array}$ & 2.08 & 41.67 \\
\hline OVERALL & 1.70 & 33.96 \\
\hline \multicolumn{3}{|l|}{ AUTHENTICITY } \\
\hline $\begin{array}{l}\text { When behaviour feedback is given to employees they take it seriously and use it for } \\
\text { development. }\end{array}$ & 1.71 & 34.17 \\
\hline $\begin{array}{l}\text { When employees are sponsored for training, they take it seriously and try to learn from the } \\
\text { programmes they attend. }\end{array}$ & 2.04 & 40.83 \\
\hline $\begin{array}{l}\text { Employees returning from training programmes are given opportunities to try out what they } \\
\text { have learnt. }\end{array}$ & 1.83 & 36.67 \\
\hline Employees are sponsored for training programmes on the basis of genuine training needs. & 2.13 & 42.50 \\
\hline OVERALL & 1.93 & 38.54 \\
\hline \multicolumn{3}{|l|}{ COLLABORATION } \\
\hline People in this organization are helpful to each other. & 1.75 & 35.00 \\
\hline Team spirit is of high order in this organization. & 1.75 & 35.00 \\
\hline $\begin{array}{l}\text { The organization's future plans are made known to managerial staff to help them develop } \\
\text { their juniors and prepare them for future. }\end{array}$ & 1.96 & 39.17 \\
\hline OVERALL & 1.82 & 36.39 \\
\hline OVERALL OCTAPAC Culture & 1.91 & 38.26 \\
\hline
\end{tabular}

Analysis and Interpretation: the above depicts the mean and per cent of the OCTAPAC Culture in the aviation companies in Bangalore.

Based on the data collected from the aviation companies it could be concluded that there is a strong Autonomy as it has the highest overall mean of 1.96 (39.17) followed by Authenticity 1.93 (38.54).

Autonomy leads to creativity as employees are encouraged to experiment with new techniques and methods as per data collected the aviation companies had a total mean of 3.38 (59.50) meaning the company fully support for creativity and innovation and many respondents strongly agreed also many respondents strongly agreed that employees retaining from training programs are given opportunities to try out what they have learned which were indicated by high percentage of 62.25 (3.49 Mean).

Also, from the data collection and analysis it shows many employees strongly don't agree on various aspects of openness in an organization, confrontation, pro activity, trust and so forth therefore, the managerial 
teams should take Initiative to find the weakness and strength of the employees and most important making using of the employee potential and an environment which motivates one to work and feel appreciated and accepted which means a positive work environment with appreciation and acknowledgement could lead to a better productivity in terms of a organisations success or functioning and a highly motivating environment and culture which acknowledges and appreciates efforts made individually and collectively.

\subsection{HRD Mechanism- Mean \& Percent}

\begin{tabular}{|c|c|c|}
\hline Item & Mean & Per cent \\
\hline $\begin{array}{l}\text { People lacking competence in doing their jobs are helped to acquire } \\
\text { competence rather than being left unattended. }\end{array}$ & 1.67 & 33.33 \\
\hline $\begin{array}{l}\text { Seniors guide their juniors and prepare them for future responsibilities/roles } \\
\text { they are likely to take up. }\end{array}$ & 1.94 & 38.89 \\
\hline $\begin{array}{l}\text { The top management makes efforts to identify and utilize the potential of the } \\
\text { employees. }\end{array}$ & 1.53 & 30.56 \\
\hline $\begin{array}{l}\text { Promotion decisions are based on the suitability of the promoted person } \\
\text { rather than based on any favouritism or partiality. }\end{array}$ & 1.53 & 30.56 \\
\hline $\begin{array}{l}\text { There are mechanisms in this organization to reward any good work done or } \\
\text { any contribution made by employees. }\end{array}$ & 1.88 & 37.50 \\
\hline $\begin{array}{l}\text { When an employee does good work his supervising officers take special care } \\
\text { to appreciate it. }\end{array}$ & 1.74 & 34.72 \\
\hline $\begin{array}{l}\text { Performance appraisal reports in this organization are based on objective } \\
\text { assessment and adequate information and not on favouritism or partiality. }\end{array}$ & 2.08 & 41.67 \\
\hline $\begin{array}{l}\text { Weaknesses of employees are communicated to them in a nonthreatening } \\
\text { way. }\end{array}$ & 1.67 & 33.33 \\
\hline $\begin{array}{l}\text { When employees are sponsored for training, they take it seriously and try to } \\
\text { learn from the programmes they attend. }\end{array}$ & 2.01 & 40.28 \\
\hline $\begin{array}{l}\text { Employees returning from training programmes are given opportunities to } \\
\text { try out what they have learnt. }\end{array}$ & 1.81 & 36.11 \\
\hline $\begin{array}{l}\text { Employees are sponsored for training programmes on the basis of genuine } \\
\text { training needs. }\end{array}$ & 2.22 & 44.44 \\
\hline $\begin{array}{l}\text { Career opportunities are pointed out to juniors by senior officers in the } \\
\text { organization. }\end{array}$ & 1.74 & 34.72 \\
\hline $\begin{array}{l}\text { The organization's future plans are made known to managerial staff to help } \\
\text { them develop their juniors and prepare them for future. }\end{array}$ & 2.22 & 44.44 \\
\hline $\begin{array}{l}\text { This organization ensures employee welfare to such an extent that the } \\
\text { employees can save a lot of their mental energy for work purposes. }\end{array}$ & 1.74 & 34.72 \\
\hline Job-rotation in this organization facilitates employee development. & 1.94 & 38.89 \\
\hline Overall HRD Mechanism & 1.91 & 38.3 \\
\hline
\end{tabular}

Analysis and Interpretation: The above depicts the mean and per cent of the HRD mechanism in the aviation companies in Bangalore.

Based on the data collected from the aviation companies it could be concluded that there is an effective communication system in the organization as the organization ensures that the plans are communicated to the 
managerial staffs to help them develop their subordinates and prepare them for future, majority of the employees strongly agreed that plans were communicated and it has a mean of 2.22 (44.44) which is the highest for HRD mechanism.

The least mean for the HRD mechanism is 1.53 (30.50) which reflected that the top management did not take initiative to identify and utilize the potentials of the employees as per the feedback provided by the airline companies in Bangalore. Also, respondents disagreed with the fact that promotion is based on merit and not on a partiality basis as it also had the least mean of 1.53 (30.50).

They also need some improvements in some areas such as; training, career opportunities, better salary packages, providing more employee welfare, career planning assistance, communicating weakness in a nonthreatening manner, provide education opportunities to broaden knowledge and bridge the gap with modern techniques and technologies, assisting in building competencies and most importantly providing promotion or transfer opportunities based on merit rather than partiality. It's wise the airline's companies can frame suitable HRM mechanisms to attract and retain talent and also creating a positive climate.

4.4 Overall View: Human Resource Development climate

\begin{tabular}{|c|l|c|c|}
\hline S. No. & \multicolumn{1}{|c|}{ Category } & Mean & Per cent \\
\hline 1 & General HRD climate in Aviation, Bangalore & 1.74 & 34.74 \\
\hline 2 & OCTAPAC culture mechanism in Aviation, Bangalore & 1.96 & 39.17 \\
\hline 3 & HRD mechanism in Aviation, Bangalore & 1.91 & 38.26 \\
\hline
\end{tabular}

As per the illustration;

OCTAPAC culture with a mean of 1.96 (39.17 percent) is relatively more prevalent than the Human Resource Development mechanism and the General Human Resource Development climate in aviation.

Moreover, OCTAPAC culture is in the first place when compared to other categories because of the high score in Autonomy, Authenticity, and Confrontation. The factors which contributed to the HRD mechanism and also made it relatively more prevalent when compared to the General HRD climate in Aviation are learning while training and implementation, competency building and so forth. HRD mechanism has an overall man of 1.96 (39.17 present) as shown above.

The important factors which were found to be contributing towards high score or moderately towards the Human Resource Development (HRD climate) are as follows; employees were not afraid to express themselves to each other or to the superiors, team spirit among the employees of the organization which is good in long term as it will lead to efficiency, competency building, top management support throughout for motivation and direction of human assets and resources used for production, mentoring and guidance of employees for self development and having clarity in the functions carried out by the individuals, job rotation for employees to build skills and development which helps one to acquire or broaden knowledge on various departmental functions, training programs designed for employees to learn and develop new skills.

\section{Conclusion and Recommendations}

The three categories of HRD climate play a vital role in any organization. Good HRD climate and HRD mechanism lead to efficiency in the organization and organizational excellence for which an organization has to improve the downfalls which they have in that case the Aviation companies in Bangalore has to focus more on creating a friendly environment where employees can feel free to communicate without the fear and at the same time promote teamwork and assist in career planning and development. Creating an OCTAPAC climate should be kept in mind and also end goals of the company. There should be a changed in the existing correspondence framework which can decrease the hole and build up a culture of trust which is observed to be poor. Furthermore, there should be a change in the criticism framework and it should be connected with training, reward and vocation framework, and keeping in mind the end goal to reinforce the working of the HRD system, as expressed before the idea of HRD can be contemplated from various points.

There are different parts of HRD, for example, training, execution examinations and criticism, potential evaluations, profession arranging, and improvement, prizes and laborer's welfare, work-life, adjust and so forth. This dissertation project for MBA was constrained just to the investigation of HRD instrument, general atmosphere and OCTAPAC culture in the aviation sector in Bangalore. The fundamental motivation behind the examination is to comprehend the impression of the specialists in the aeronautics area as far as the initiative, correspondence, coordinated effort, independence inside the association and the different instrument utilized by the organization to hold representatives and making a decent workplace and culture.

Few suggestions upon research could be organizations to enhance the HRD atmosphere in the general population and in aviation industry in Bangalore the bosses must be open to every one of the specialists, listen closely in instances of inquiries to make timely decision and have open mind and perspectives and encourage two-way communications for the organizational and operational excellence. Listening to inquiries would 
motivate employees to speak up or report issues rather than sitting at a place not bothered as to what's happening around to take immediate actions.

Seniors urge their subordinates to think about their improvement and make a move toward that path for organizational excellence and productivity overall. Senior officers to look into it closely to mentor, couch the subordinates to see they achieve the set goals or path of success they can monitor or see performances and improvements on a monthly or yearly basis to forecast the improvements made and if there has been an initiative from employees for improvements.

The administration should direct conceptualizing sessions which will produce new and creative thoughts and furthermore joint effort among workers, after all, to cope up in the business world businesses need competitive, creative and very innovative human resource for which they have to direct the human resource or conduct session wherein, it builds the team stronger which is bonding and coming up with exclusive ideas and concepts for efficacy. The administration should also make honest to goodness endeavors to change conduct based on criticism got so that they can act upon that criticism and come up with more creative ideas and deal with issues or problems arising in the organization in a more formal manner rather than being ignorant to issues or taking matters pertaining in a stricter and ignorant manner. Criticism could be taken positively or negatively but it's advisable to take note of the points and work on it for improvements rather than taking it too seriously or feeling offended it's wise to give it a thought, improve and move on producing better results and proving yourself in a competitive workforce.

Transparency in correspondence required at all levels for better comprehension of work and better holding among people so that there is an ease of communication upwards and downwards the organization hierarchy to encourage direct communication and passing of information promptly for work to be done predetermined to achieve long term strategies and objectives of the company. Transparency at the workplace is crucial in companies this day due to the frequent changes in policies and strict monitoring. Employees should feel obliged to work for the company and feel the fair treatment and a willingness to walk up and speak for him or herself or having proper channels to reach out to authorities concerned in case of doubts or inquiries or policy which are transparent to all.

And finally, employee fulfilment review must be done at normal interim to get the genuine picture of work culture and the changes to be brought forward for a better chance and a healthy work environment and overall productivity and furthermore to discover the changing state of mind among the workers. As companies place with people from various backgrounds it's wise to have an encouraging and welcoming culture and environment to make one feel accepted and keen to serve you therefore, OCTAPAC culture must be paid attention to have a good work environment to motivate employees to give their best in what they do which in long run would be beneficial not just for an employee to have an open mind and willingness to work but also for the company as it will project better results in terms of its operational efficiency rates and overall excellence and productions.

\section{References}

Aileni, V.R., and Prasad, S., 1995. View of association atmosphere and occupation fulfillment. The Journal of Training and Development, July-Dec, 6-13.

Famina, A. (2009).OCTAPACE Profile and Human Resource Climate in a South Asian Public Sector Undertaking with Special Reference on KSFE. Pranjana: The Journal of Management Awareness, 12(2). India Brand Equity Foundation (2018) "Indian Aviation Industry", viewed on 14/05/2018 in the IBEF website, https://www.ibef.org/industry/indianaviation.aspx.

Indigo (2017-2018). "Indigo History and plans", viewed on 04/05/2018 in the Indigo website, https://en.IndiGo\#History.

Jain, V.K. and Singhal, K.C., 1997. Some Correlates of HRD Climate: A Case Study of BHEL, Studies in Human Resource Development: HRD Practices: Assimilation and Implications; Deep and Deep Publications, Vol.3; New Delhi, pp. 213-219.

Jet Airways (2017) "Jet Airways", viewed on 05/05/2018 in the Jet Airways website, https://www.jetairways.com/en/us/home.aspx.

K. Aswathappa (2010), Human Resource Management, Tata McGraw-Hill Education.

Kalburgi, M Srinivas (1984). Human Resource Management, Toronto: McGraw Hill.

MBA school.com (2018) "Brand Guide Airlines", viewed on 08/05/2018 in the MBA School.Com website, https://www.mbaskool.com/brandguide/airlines/388indigo-airlines.html.

Pillai, P.R. 2000.Impact of HRD Climate on the Learning Orientation of Bank Employers. Indian Journal of Industrial Relation, Vol.43, No.3, pp. 406-418.

Purang, P. 2006. Human resource development Climate: A Comparative Analysis of Public, Private and Multinational Organizations.Indian Journal of Industrial Relation, Vol. 41, No.3. pp. 407-419.

Saraswathi, S. (2010). Human Resources Development Climate: An Empirical Study. International Journal of Innovation, Management, and Technology, 1(2), 174-179. 
Solkhe and N. Choudhary, 2011. HRD Climate and Job Satisfaction: An Empirical Investigation. International Journal of Computing and Business Research, 2(2).

Srimannarayana, M.,(2007.) Human Resource Development Climate in Dubai Organizations. Indian Journal of Industrial Relation,Vol. 43, No. 1, July, pp.1-12.

Srimannarayana, M., 2007.Human Resource Development Climate in the Manufacturing Sector. Indian Journal, Management, and Change, Vol. 13, No. 2 (2009), pp.138-141.

Tripathi, S. and Tripathi, N., 2002.The Effect of Organizational Climate on Organizational Success. Indian Journal of Industrial Relation, Vol.38, No.2, pp.160174.

Wani, T. A. (2013). An empirical study of Human resource development Climate and OCTAPAC Culture in FMCG Companies in India: A Case Study of Cadbury India-Thane Plant. International Monthly Refereed Journal of Research In Management \& Technology, 100-106.

World Blaze (2018) "Top 10 best airlines of India", viewed on 28/05/2018 in the World Blaze website, https://www.worldblaze.in/indias-top-10-best-airlines/.

First A. Archana Sitamma Reddy born Labasa, Fiji Islands, 22nd January 1993. Academic Scholarship to India for Bachelor in Commerce 2011-2014(BCom) from Savitribai Phule Pune University, Pune, Maharashtra, India and Masters in Business Administration 2016-2018 (MBA in Finance \& Human Resource) from Bangalore University, Bangalore, India. (archanar@unifiji.ac.fj / archana_redz@yahoo.com) 